
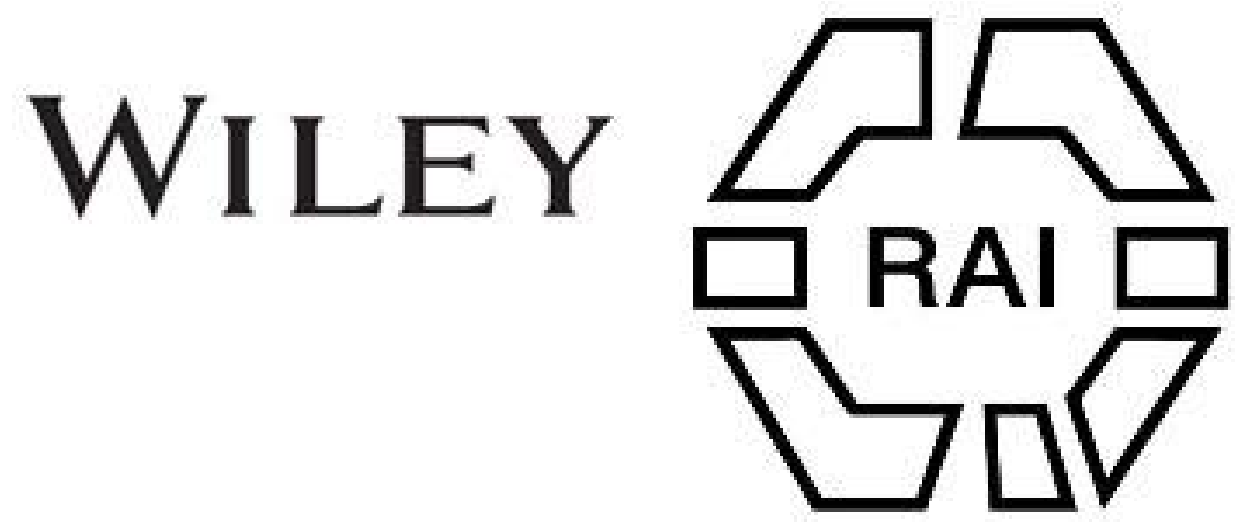

\title{
83. Prehistoric Egyptian Pottery.
}

Author(s): W. M. Flinders Petrie

Source: Man, Vol. 2 (1902), p. 113

Published by: Royal Anthropological Institute of Great Britain and Ireland

Stable URL: http://www.jstor.org/stable/2839477

Accessed: 27-06-2016 01:11 UTC

Your use of the JSTOR archive indicates your acceptance of the Terms \& Conditions of Use, available at

http://about.jstor.org/terms

JSTOR is a not-for-profit service that helps scholars, researchers, and students discover, use, and build upon a wide range of content in a trusted digital archive. We use information technology and tools to increase productivity and facilitate new forms of scholarship. For more information about JSTOR, please contact support@jstor.org.

Wiley, Royal Anthropological Institute of Great Britain and Ireland are collaborating with JSTOR to digitize, preserve and extend access to Man 
Man, 1902. Plate H.
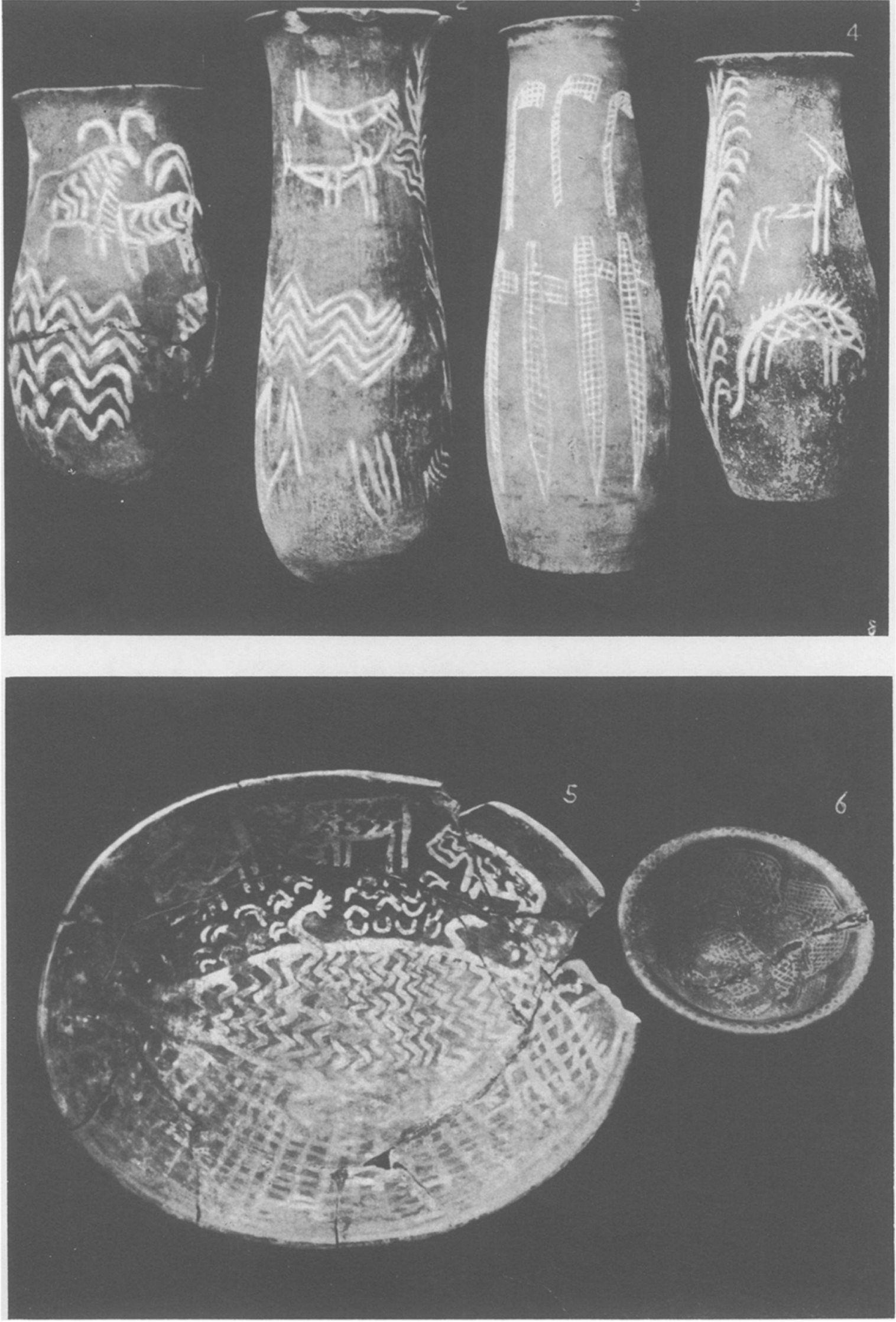

PREHISTORIC EGYPTIAN POTTERY.

This content downloaded from 128.163.2.206 on Mon, 27 Jun 2016 01:11:43 UTC All use subject to http://about.jstor.org/terms 


\section{ORIGINAL ARTICLES.}

Egypt.

With Plate $\mathrm{H}$.

Petrie.

Prehistoric Egyptian Pottery. By W. M. Flinders Petrie, D.C.L., 83
L.D., Edwards Professor of Egyptology in University College, London.

The earliest class of pottery known in prehistoric times in Egypt was the red polishel ware, and on almost the earliest examples of this (sequence date 31-34) are found the paintings in white line, which belong therefore to the oldest civilisation known in the country. Animal figures are not very common on these designs, and the examples here shown (Plate H.) are some of the best that I have seen. All the figures are on the scale of one third.

1. Jar with figures of goats on it, drawn in the usual manner. This class of cross lined pottery with very thick white lines has not been found in any of our excavations north of Thebes ; it is said to come from Gebeleyn.

2. Jar with two animals and plant pattern up the side.

3. Jar with two rows of objects around it, which are otherwise unknown. The upper figures might be adzes or hoes, the lower figures are curiously like lictors' fasces, but no such forms are known in Egypt ; they may, however, be a form of stone axes set in handles. Certainly neither can be the hieroglyphic neter sign, as that had double projections down to dynastic times.

4. Jar with a deer and a hedgehog, and plant pattern up the sides.

5. Large dish with a crocodile filling the bottom of it, and three hippopotami on the upper edge. Below the crocodile is a cross pattern which might be intended for water ripples.

6. Small dish with five hippopotami round the sides; the dish is tilted to show one side completely, and thus the other side is foreshortened. In the middle are three fishes.

W. M. FLINDERS PETRIE.

Totemism.

Hartland.

An American View of Totemism: a Note on Major Powell's 84
Article. MaN, 1902. 75. By E. Sidney Hartland, F.S.A.

I entirely agree with Major Powell in the conviction, which evidently underlies his remarks, of the necessity of defining our terms if we would make any progress in the study of Totemism. In some respects I am inclined to go further than he does. For example, I demur to using the term totem, even when qualified as individual totem, for the name assumed by a youth at puberty, or for his protecting spirit or being revealed to him during ecstasy. It may be that in the Algonquin languages the clan-totem and the individual totem are both called totem. But we have not yet determined the relationship between these two orders of superior beings; and until we do so I think it would be well to denominate them by distinetive uames about which there can be no confusion. Is there any objection to the word Manitou as the designation of what has been called the individual totem? This word is, I think, actually used by some of the American tribes for the purpose; and its provisional employment by us would tend to clearness of expression and of thought.

Similar observations apply to the presiding genius, or deity, of a shamanistic society, and that of a tribe. Confusion must result if we do not keep them separate and distinct from those of the clan and the individual, by means of terms which wil not prejudge the question of their relations. Major Powell does not refer to what have been called sex-totems. They are not an American phenomenon. It seems to me they have as much-and as little-claim to be considered totems as the deity of a shamanistic society. 